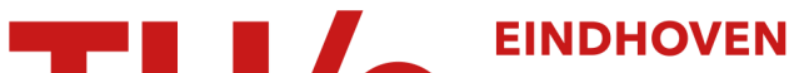 UNIVERSITY OF TECHNOLOGY
}

\section{Fueling connections between chemistry and biology}

\author{
Citation for published version (APA): \\ Van Der Zwaag, D., \& Meijer, E. W. (2015). Fueling connections between chemistry and biology: chemical \\ reactions create far-from-equilibrium materials by mastering self-assembly. Science, 349(6252), 1056-1057. \\ https://doi.org/10.1126/science.aad0194
}

DOI:

10.1126/science.aad0194

Document status and date:

Published: 04/09/2015

\section{Document Version:}

Accepted manuscript including changes made at the peer-review stage

\section{Please check the document version of this publication:}

- A submitted manuscript is the version of the article upon submission and before peer-review. There can be important differences between the submitted version and the official published version of record. People interested in the research are advised to contact the author for the final version of the publication, or visit the $\mathrm{DOI}$ to the publisher's website.

- The final author version and the galley proof are versions of the publication after peer review.

- The final published version features the final layout of the paper including the volume, issue and page numbers.

Link to publication

\section{General rights}

Copyright and moral rights for the publications made accessible in the public portal are retained by the authors and/or other copyright owners and it is a condition of accessing publications that users recognise and abide by the legal requirements associated with these rights.

- Users may download and print one copy of any publication from the public portal for the purpose of private study or research.

- You may not further distribute the material or use it for any profit-making activity or commercial gain

- You may freely distribute the URL identifying the publication in the public portal.

If the publication is distributed under the terms of Article 25fa of the Dutch Copyright Act, indicated by the "Taverne" license above, please follow below link for the End User Agreement:

www.tue.nl/taverne

Take down policy

If you believe that this document breaches copyright please contact us at:

openaccess@tue.nl

providing details and we will investigate your claim. 


\section{New fuel to bridge chemistry and biology}

Chemical fuels are used to create far-from-equilibrium materials by mastering self-assembly

\section{By Daan van der Zwaag and E.W. Meijer}

Many biological functions are the result of the strong and directional interactions between subunits constituting the cellular structure. These self-assembly processes display rich dynamic behavior, where growth and shrinkage are carefully controlled by biochemical feedback mechanisms. One of the most fascinating examples is the GTP-mediated assembly and disassembly of tubulin into microtubules (1). The realization of a chemically fueled synthetic system is a long-standing challenge in the field of supramolecular chemistry (2). A seminal step towards a full mimic of the cellular cytoskeleton has now been achieved by Eelkema, Van Esch and collaborators on page xxxx of this issue (3). The authors demonstrate the far-from-equilibrium self-assembly of molecular subunits driven by a chemical fuel, leading to the transient formation of fibrous hydrogel materials. The farfrom-equilibrium conditions result in peculiar self-assembly processes unprecedented in synthetic systems, mimicking in part the fluctuations observed in microtubules.

Microtubules are part of the cellular cytoskeleton, a dynamic and adaptive self-assembled network that is critical for achieving compartmentalization, generating directed forces, and facilitating intracellular traffic (4). Individual microtubules display complex assembly dynamics, alternating between regimes of stable growth and catastrophic disassembly. This dynamic instability greatly increases the ability of the fibers to reorganize and cover large volumes of cellular space (5). The mechanism underlying the dynamic instability - simultaneous GTP-driven growth and GDPinitiated shrinkage - relies on the critical composition of the so-called GTP-rich cap, i.e. far-fromequilibrium conditions (6).

While chemists are able to construct responsive one-dimensional fibrous structures (2), the assembly-disassembly processes reported so far are all based on changing the equilibrium conditions; i.e. one stable aggregate state is converted to another or to the monomer state. Illustrative examples include the enzyme-mediated self-assembly of peptide oligomers (7), photochemically tuned (dis)assembly of Zn-porphyrins (8), and the ATP-induced helix inversion of chiral fibers (9). These processes have all been appropriately described by equilibrium models (10). Kinetic studies that take pathway complexity into account (11) have advanced our understanding of responsive synthetic fibers, despite the paucity of far-from-equilibrium systems investigated thus far.

As early as 2010, Eelkema, Van Esch and collaborators disclosed first results on the use of chemical fuels to power supramolecular polymerizations (12). In their strategy a charged, inactive dicarboxylic monomer is transformed into an activated diester by alkylation, yielding a fibrous structure through aggregation. Competitive hydrolysis of the diester resulted in the eventual degradation of the supramolecular polymer. The addition of subsequent portions of alkylating agent resulted in new cycles of supramolecular polymerization followed by depolymerization. How have the authors converted this concept into a fundamental step towards far-from-equilibrium conditions? They increased the rate of the reactions involved in the supramolecular cycle, leading to an increase of the concentration of fibrous filaments. This in turn led to the transient formation of hydrogels with storage moduli of up to $10 \mathrm{kPa}$. By independently controlling alkylation and 
hydrolysis, the materials' properties and lifetime can be tuned. Although immediate applications of these gels are hard to foresee due to the toxic nature of the dimethylsulfate fuel, the far-fromequilibrium conditions allowed the authors to observe some of the more appealing characteristics of dissipative self-assembly: stochastic fiber collapse and simultaneous growth and shrinkage, both reminiscent of microtubule dynamics (see the figure).

A detailed analysis of the fibers during one chemical cycle using confocal microscopy enabled the authors to quantify the growth rate of each individual filament. This single-aggregate analysis is critical, since the average length changed gradually and did not show any characteristic signs of dissipative self-assembly. At the individual fiber level, however, detailed insights into the assembly mechanisms emerged. Initially, fast fiber growth occurs universally due to the abundance of activated monomers. When the fuel is consumed, hydrolysis competes with activation, leading to the effects illustrated in the figure. First, catastrophic fiber collapse is observed indicating a threshold of hydrolyzed subunits in the fiber, below which shrinkage takes place. Second, the collapse occurs solely at fiber ends and may thus be rescued by patches of non-hydrolyzed subunits resembling the microtubule GTP-cap. Third, renewed growth after fuel depletion is facilitated by the release of activated monomers from concurrently degrading fibers. Finally, after complete hydrolysis, the remaining fibers collapse.

Although this behavior is surprisingly similar to microtubule dynamics, some facets are still to be designed and integrated in order to arrive at artificial life-like systems. Several important challenges can be set. How do we convert the responsiveness of fibrous materials to macroscopic work? How do we couple the transient growth of these materials to active networks with positive and negative loops based on interacting chemistries? And finally, how are all these components integrated? We foresee that progress in supramolecular polymerization will soon lead to the rational design of highly ordered filaments which can be used to perform mechanical action. Furthermore, recent advances in systems chemistry, combined with an increasing understanding of isolated biochemical networks, will undoubtedly allow chemists to optimize chemical networks in a holistic way. However, the true challenge lies in achieving the synchronized operation of optimized filaments with materials functionality and chemical networks.

1. A. Desai, T. J. Mitchison. Annu. Rev. Cell Dev. Biol. 13, 83-117 (1997).

2. T. Aida, E. W. Meijer, S. I. Stupp. Science. 335, 813-7 (2012).

3. J. Boekhoven, et al. Science. Placeholde.

4. D. A. Fletcher, R. D. Mullins. Nature. 463, 485-92 (2010).

5. T. E. Holy, S. Leibler. Proc. Natl. Acad. Sci. 91, 5682-5685 (1994).

6. M. Kirschner, T. Mitchison. Cell. 45, 329-342 (1986).

7. S. Toledano, et al. J. Am. Chem. Soc. 128, 1070-1071 (2006).

8. T. Hirose, F. Helmich, E. W. Meijer. Angew. Chemie Int. Ed. 52, 304-309 (2013).

9. M. Kumar, et al. Nat. Commun. 5, 5793 (2014).

10. P. Jonkheijm, et al. Science. 313, 80-83 (2006).

11. P. A. Korevaar, et al. Nature. 481, 492-496 (2012).

12. J. Boekhoven, et al. Angew. Chem. Int. Ed. Engl. 49, 4825-8 (2010).

Institute of Complex Molecular Systems, Eindhoven University of Technology, P.O. Box 513, 5600 MB Eindhoven, the Netherlands 
A<smiles>O=C(O)CSSCC(NC(=O)c1ccccc1)C(=O)O</smiles>
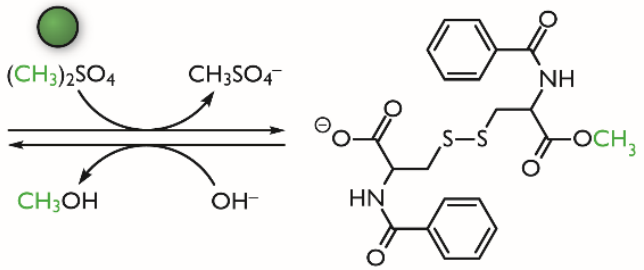

B

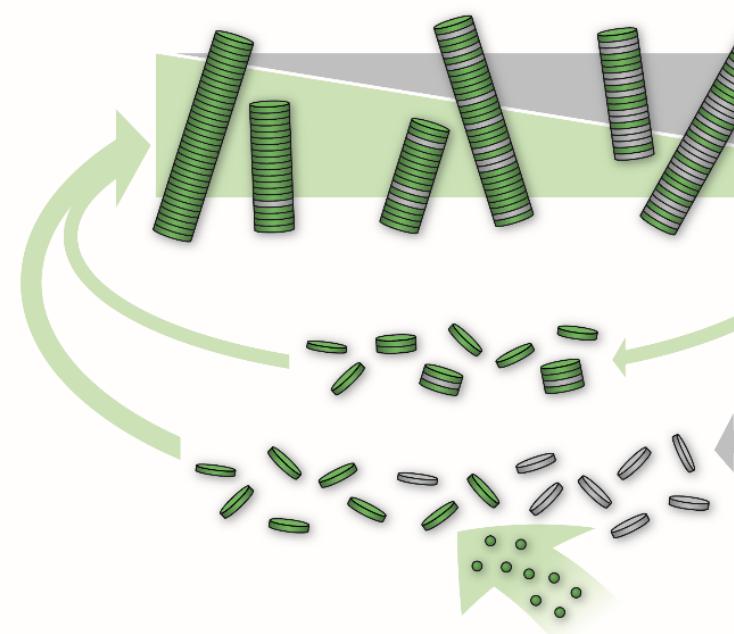

C

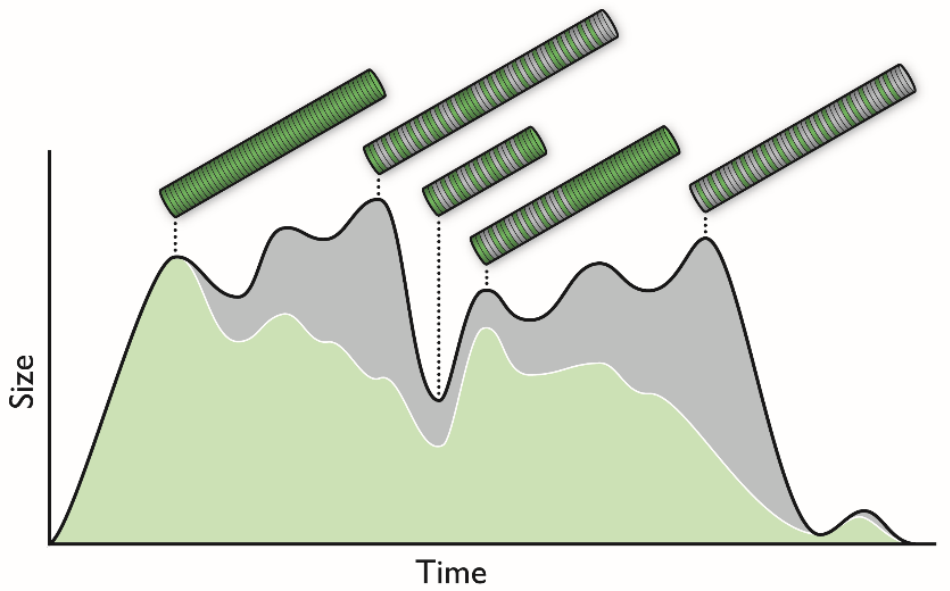

Fuel-driven supramolecular polymerization. (A) The interconversion of non-active and active monomers. (B) The (dis)assembly of the subunits given in A into one-dimensional fibers. (C) The occurrence of sustained growth and catastrophic collapse in a single fiber. The black line represents the total fiber length; the white line indicates the number of active subunits in the fiber. 